\title{
ALBA IULIA-LUMEA NOUĂ SITE (ROMANIA): HISTORICAL EVOLUTION FROM NEOLITHIC SETTLEMENT TO A MODERN RECREATION AREA
}

\author{
Ioana Borca ${ }^{1}$, Mihai Gligor ${ }^{2}$, Cornel Tatai-Baltă $\breve{3}^{3}$
}

\begin{abstract}
This article highlights the archaeological and geographical importance of the Alba Iulia-Lumea Nouă settlement and its functional development throughout history. Situated in a millenary city, the settlement displays obvious traces of the contribution of the civilizations that transformed and adapted the local geographical features according to their constant changing needs. Prehistoric and modern elements from painted pottery and the distinctive mortuary practices of various Neolithic and Eneolithic cultures, the 18th and 19th century military plans, together with Arthur Bach's collection of photos illustrating a 20th century park, reveal the true value of this site. Drawing on these resources, we present a historical landscape analysis of the Neolithic to Modern Ages in the context of cultural change.
\end{abstract}

UDC Classification: 94(3/9), DOI: http://dx.doi.org/10.12955/cbup.v4.780

Keywords: Alba Iulia-Lumea Nouă, prehistoric archaeology, landscape, modern garden.

\section{Introduction}

The main purpose of this paper is to gather viable information in situ to reassemble historical information about a particular green space and its connection to the landscape. An essential aspect of this study relates to the forgotten origins of the ancient settlement founded at this green space. The study aims to reveal this settlement's genesis and analyze the social, cultural, and climatic environment that favored human existence in this area. Evlia Çelebi wrote, in his famous 17th century "Seyâhatnâme", of Alba Iulia as being a pleasant city with fresh water, beautiful gardens, and wines (Moga, 1987). In terms of landscape design within the city and its surroundings, reference can be made to remarkable Roman medieval and modern gardens that have been noted throughout various historical periods and which can still be admired today. One such site is Lumea Nouă, which has been a subject of study for over 70 years. Archaeologists have established this site as one of human habitation since the mid-Neolithic, based on traces of dwellings, archaeological artefacts, and faunal, botanical, and human remains. It has been inferred that in prehistoric times the inhabitants were farmers who tended livestock and manufactured artefacts (pottery, bone and horn tools and jewelry, lithic tools and weapons, and anthropomorphic and zoomorphic clay figurines). In addition, they were the bearers of Vinča, Lumea Nouă, Turdaș, Foeni, Petrești, and Coțofeni culture (Berciu 1968; Gligor, 2003; 2007; 2009). In the Neolithic and Eneolithic periods, the species of wheat cultivated at Lumea Nouă were Triticum dicoccum and Triticum aestivum. Traces of Fabaceae family (legume) cultivation have also been observed, specifically of Vicia ervilia, an ancient roman crop, known to have been used in rudiment production, as well as for food. Remains of Cornus sp. (dogwood) indicate its use in the diet of the ancient inhabitants. Wild plants like Chenopodium sp. (goosefoots) had an important role, assuming that those who consumed it were aware of the plant's nutritional properties (Ciută, 2009; Gligor, 2009).

During the Habsburg Empire, several surveys were completed that were relevant to urban planning and future development of the site (Figure 1). The Austrian map that describes Lumea Nouă as Neue Welt (Figure 2) and refers to a swampy region is particularly relevant to this study. From a Neolithic settlement to a Bishop's Summer Garden in the Middle Ages, and then a 20th century restaurant, Lumea Nouă has undergone numerous transformations throughout the ages and has changed function as the physical and social needs of its resident humans developed.

\section{Geographical Landmarks}

The Alba Iulia-Lumea Nouă site is part of Alba County, a region of Transylvania (Romania). Situated in the north-east of the famous historical city, on the second terrace of the Mureş River, it is known to have a special relationship with the surrounding area. The local environmental conditions, such as the microclimate, hydrography, soil characteristics, climate, flora, and fauna, are described below.

\footnotetext{
${ }^{1}$ Ing. Ioana Borca, "1 Decembrie 1918" University of Alba Iulia, Romania; e-mail: ioana_borca@yahoo.com.

${ }^{2}$ Associate Professor Mihai Gligor, "1 Decembrie 1918" University of Alba Iulia, Romania; e-mail: mihai.gligor@uab.ro.

${ }^{3}$ Professor Cornel Tatai-Baltă, "1 Decembrie 1918" University of Alba Iulia, Romania, e-mail: ctataibalta@ yahoo.com.
} 
Figure 1: First Military Survey (1763-1787) - Kalsburg

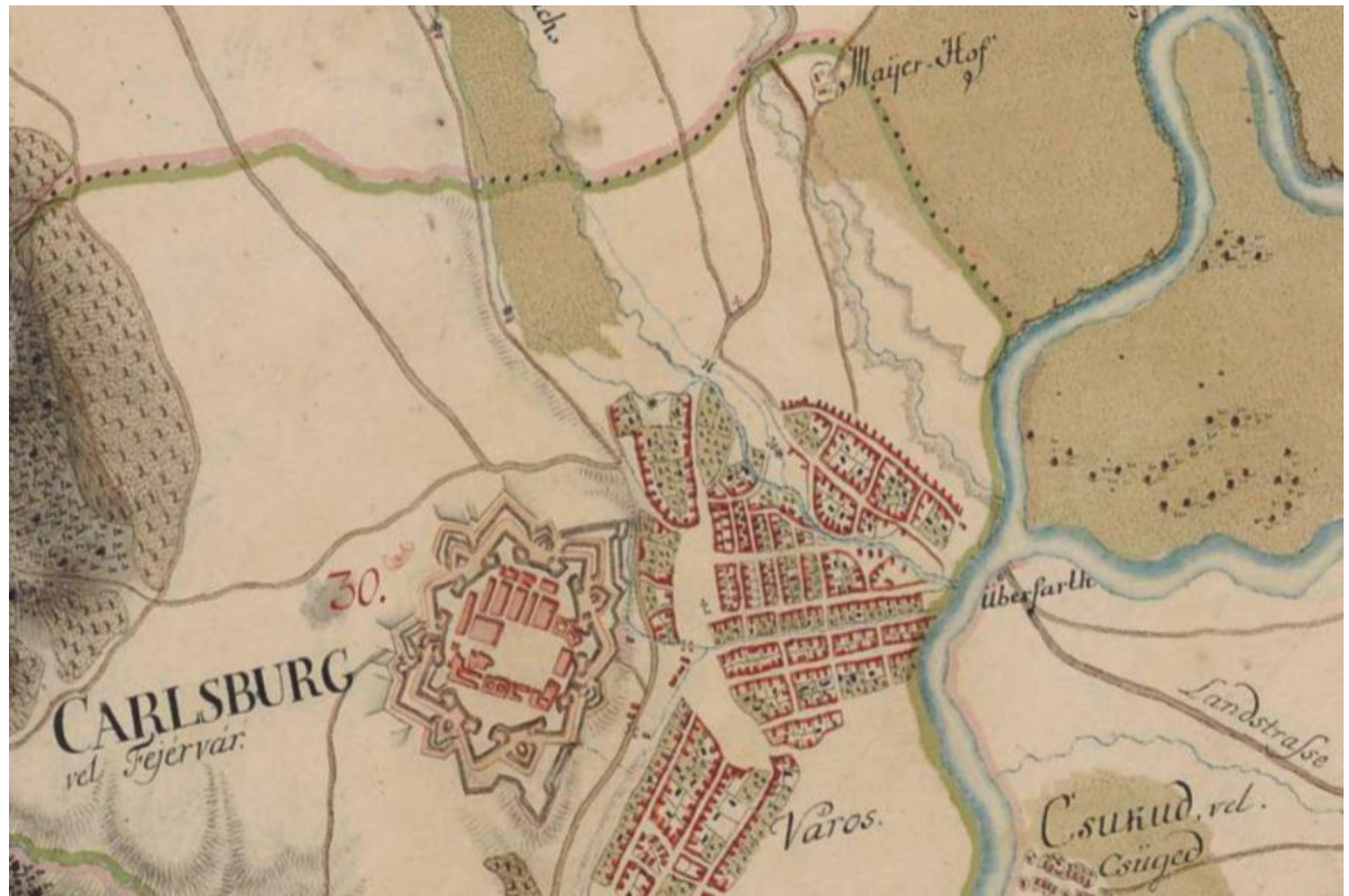

Source: Mapire (2016)

Figure 2: Second Military Survey (1806-1869) - Karlsburg

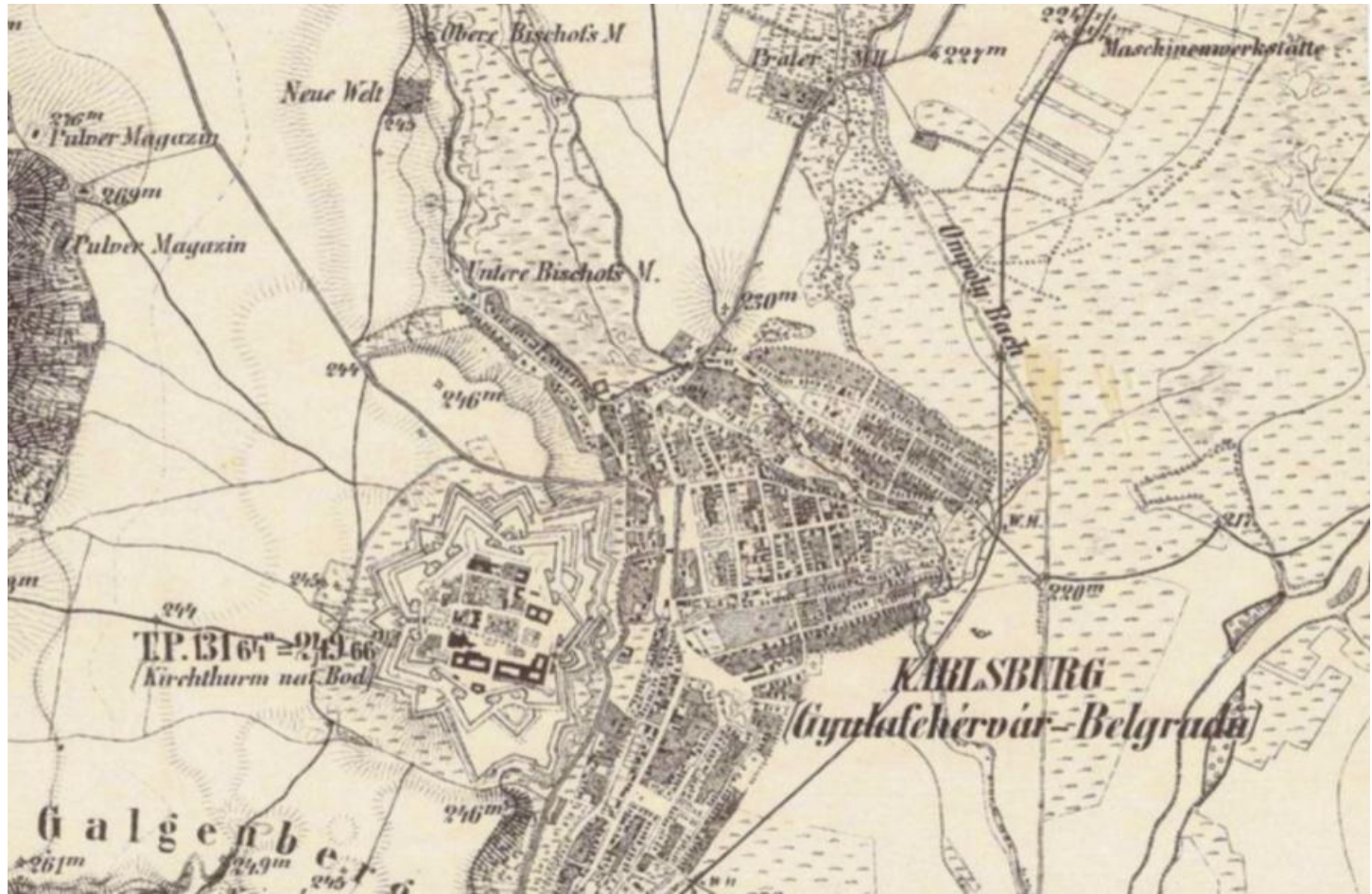

Source: Mapire (2016) 
The presence of water probably encouraged the original inhabitants to form permanent settlements at the site. The River Mureș, currently $3.5 \mathrm{~km}$ away, was presumed to have been closer in prehistory, and the course of the Ampoi, a tributary of the Mureș, was in proximity of the site (Gligor, 2009).

The site's location on the second terrace of the city's main river has a meteorological effect on the microclimate, encouraging thermal inversion and formation of fog during cold seasons. Different types of soil are found on either side of the river, but alluvial soils are dominant due to the mechanical action of the once-navigable watercourse.

The deciduous forest is an essential presence in the landscape. The vegetation is today represented by Quercus sp. (oak), but in the Neolithic period it consisted of mixed spruce with hazelnut and oak phases (Gligor, 2009). In the former Bishop's garden, beautiful ancient trees, mostly oaks, can still be admired, but otherwise the area is now basic agricultural land (Figure 3).

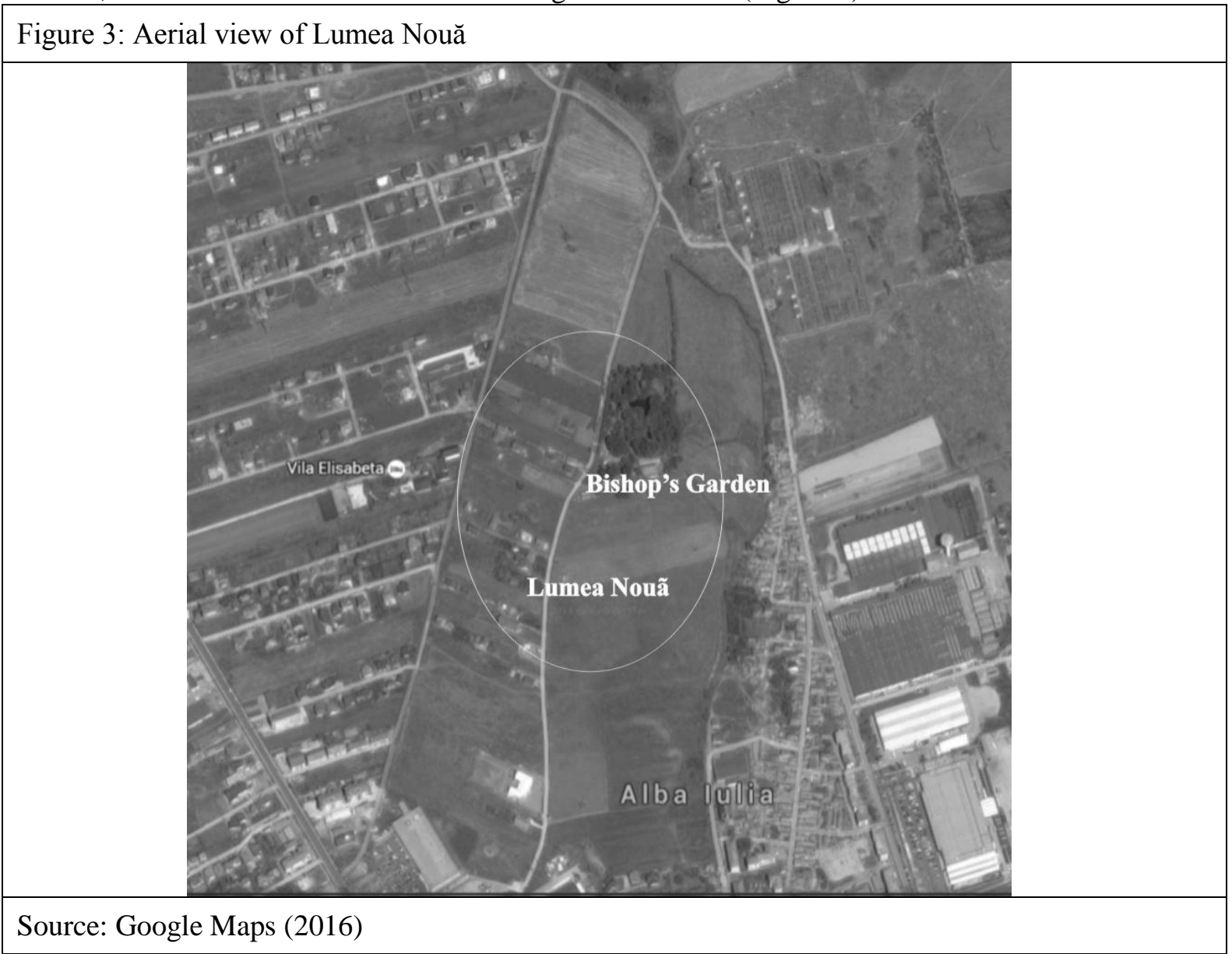

\section{Archaeological Site}

The Neolithic and Eneolithic settlement of Alba Iulia-Lumea Nouă was discovered by chance in 1942, while town planning works were being carried out. Since the 1940s, several archaeological campaigns have taken place at the site. Following extensive archaeological excavations and the establishment of research units in various parts of the site, the size of the settlement area was determined as more than 40 ha (Figure 3). Based on stratigraphical information, the earliest inhabitation at Lumea Nouă was by members of the Vinča cultural group. Up to the present time, the technique of bichrome and trichrome painting has been the only decorative approach safely attributed to the Lumea Nouă culture. The latest research provided proof of intense habitation by the Foeni cultural group, who formed the first Eneolithic communities in the intra-Carpathian area. Communities of the Petreşti, creators of an outstanding Transylvanian Eneolithic civilization, have also been identified, mostly through painted pottery that has been attributed to them (Gligor 2003; 2007; 2009).

A distinctive funerary complex that attests to mortuary practices unique to the present-day territory of Romania, has been the focus of recent research. Rescue excavations have so far uncovered three burial 
pits (in 2003, 2005, and 2011) containing disarticulated skeletal remains. Osteoarchaeological analyses have determined the presence of children, and male and female adults. Research established the MNI (Minimum Number of Individuals) for the entire skeletal collection was 85. At least ten adults in the Lumea Nouă assemblage displayed blunt force trauma to the skull in the form of depression fractures. Other archaeological material associated with the funerary discoveries was classified as originating from the Foeni culture (Gligor, 2009, 2010, 2013; Gligor, Roșu, \& Panaitescu, 2012). The chronological timeframe indicated by the Accelerator Mass Spectrometry (AMS) dating of material taken from the skeletal remains was 4600 to 4450 calibrated years before Christ (cal BC). One possible explanation for the distinctive mortuary practices found here is that Alba Iulia-Lumea Nouă was a ceremonial center, where early Eneolithic communities practiced organized burial, perhaps as part of a sacrificial ritual (Gligor, 2010, 2013, 2014; Gligor \& McLeod 2014; Gligor \& McLeod, 2015).

\section{A Recreational Garden in the Modern Age}

Lumea Nouă, otherwise Neue Welt (in German), New World (in English), or Ujvilág (in Hungarian), was mentioned in the second military survey (1806-1869). The property had belonged to the Roman Catholic Bishopric since Medieval times. To the east of Lumea Nouă, which was now the Bishop's Summer Garden, appeared a place called Prater, which was a hunting park (Stanciu, 2015). In the 20th century, the church domain was accessible to the public through a terrace and park, which was popular. Members of high society came to Lumea Nouă to relax and play sports, just like they would in any other large city of that time. The forest, fishponds, and boating wharfs created a space with multiple functions like no other in Alba Iulia. Transylvanian landscape design, from the Habsburg Empire period, reflected knowledge of gardening techniques, and a love for tradition, with a great interest in horticulture manifesting through the cultivation of new plants (Iliescu, 2008; 2014).

Sub Arini Park (Sibiu) and Dumbrava Furcilor Promenada Park (Cluj-Napoca) are just two examples of the kind of outstanding works of art that the 19th century offered to citizens (Milea, 2011). Public access and morphological characteristics, such as the swampy region (Sub Arini) or proximity to the river (Someș - Promenada Park Dumbrava Furcilor), resemble that of Lumea Nouă. Each of these parks developed in a unique way, within and outside the city, with the same purpose: to create functional green space.

In the interwar period, the place was especially destined for leisure activities, such as forest walks, admiring ancient trees, tennis playing, or paddling in the lake.

However, in 1965 the Communist regime once more changed the function of Lumea Nouă, converting it into the Roman Catholic Bishopric farm that still exists today (Timonea, 2015). Converting this beautiful park into a farm meant restriction of public access. In addition, many landscape features either disappeared or became degraded and thus, this phase involved great loss, in terms of access to green spaces and places of natural beauty for the community.

\section{The Landscape Design of Lumea Nouă 20th Century Gardens}

Arthur Bach's collection of photographs of Lumea Nouă (Figure 4) show useful historical insight into the 20th century gardens. The photographs create a pathway back in time through which we can admire the horticultural and material elements of the gardens, as well as analyze the landscape and identify some general aspects. For example, upon entry, romantic and rustic elements welcomed the visitors in the garden, which indicated a mixed design style. Narrow paths, leading to the main buildings, along with the alignment of trees and bushes, suggested a geometric style, while irregular forms and the presence of massive groupings were further features of the landscape design. The variety of flora, including trees, shrubs, and flowers, indicated a preoccupation with horticulture that probably began in the days of the Bishop's Summer garden (judging by the size of some trees), and was advanced during the Modern Age (Cserni, 1888). Wood, along with water, was the most represented element in the landscape, and created a subtle transition between the natural environment and garden. The three lakes, designed for paddling, and as fishponds, had both regular and irregular shapes. Today, only two are filled with water, reminiscent of the romantic ambiance of the garden's past. Betula pendula (silver birch) was widely used in the fences, giving the garden a countryside feeling. The same sensation would have been encountered on the terrace, where the outdoor wooden furniture would have been used during festival seasons. The landscape design transcended the idea of 
a garden more appropriately than of a park, although the space was not, logistically, large enough to be categorized as such. The use of groupings, lines, individual planting, and floral patterns in the design showed a particular way of managing spatial relationships to create a historic entity within Alba Iulia.

Figure 4: Arthur Bach's Photographic Collection of Lumea Nouă
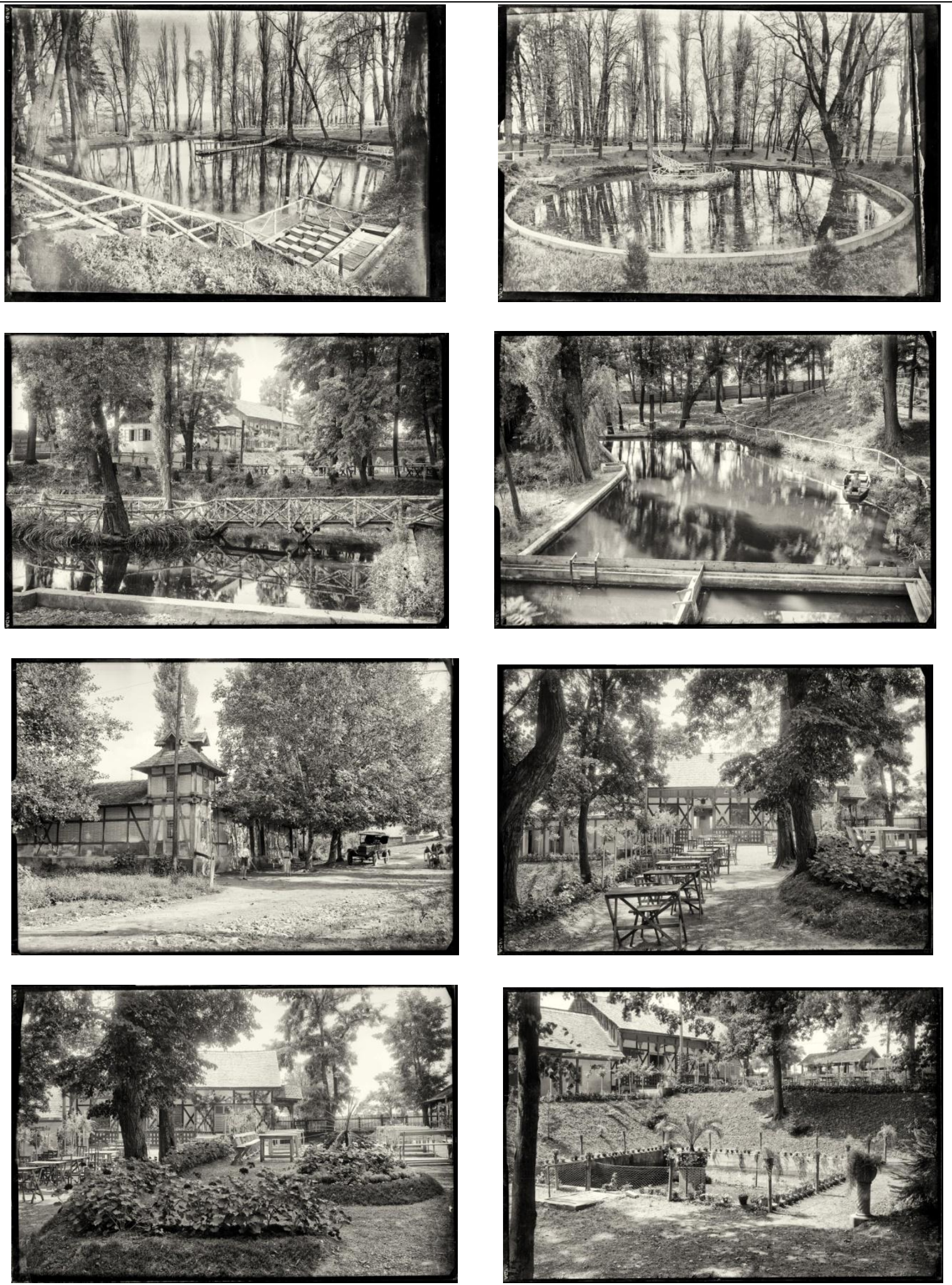

Source: Stanciu (2015) 
The monotone rhythm was successfully broken by creating flower beds and borders or slopes in the plane of sight, which to the human eye induced a gentle play between contrasting elements of large and small. A photo of a composition involving a half buried pot showed reminiscence of an Islamic garden, while the design idea of planting an orchard below the level of paths facilitated both admiration and fruit picking.

Analysis of morphological characteristics of the flora in these photographs, such as bark, leaves, inflorescence, and habitus led to the conclusive identification of 13 species including trees, bushes, and flowers, most of them typical for the local pedoclimatic conditions. The swampy region appeared to be favored by species, such as Populus sp., Salix sp., and Fraxinus sp., near the lakes, along with undetermined water plants. In sunny places, close to the terrace and around the entrance of the building, the photographs captured impressive examples of Tilia sp. and Juglans sp., while on the slopes they showed Abies sp., Juniperus sp., and Thuja sp. An area for exotic species was characterized by potted Cordyline sp. and Phoenix canariensis, placed in the most transited area, the terrace. Hibiscus syriacus and Rosa sp. followed narrow paths that were adorned with Pelargonium sp. beds that would have bordered the garden during the summer.

Most likely, the number of species would have greatly exceeded these 13 examples, but the level of detail in the black and white photos did not, at the time of this study, permit confident identification of any other species. Despite this limitation, the collection offers insight into a historic place of leisure applicable to the last century.

\section{Conclusion}

This study presented an archaeological settlement as an open anthropology book that changed in function as society around it changed through history. Natural resources of water, woodland, and rich soils were among the elements that sustained a particular segment of civilization. In modern times, Lumea Nouă has become a source of inspiration regarding garden design, especially of the early 20th century, and has retained the unique heritage of our prehistoric ancestors.

There is nothing more important in understanding a historical profile of a site than finding its roots, to know the cultural context that interacted with and influenced different ages while still allowing it to develop in contemporary history. Otherwise the landscape is submitted to a feared enemy of humankind: oblivion.

\section{Acknowledgement}

This work was supported by a grant from the Romanian National Authority for Scientific Research, CNCS-UEFISCDI, project number PN-II-RU-TE-2012-3-0461.

\section{References}

Berciu, I. (1968). Importanța complexului neolitic Lumea Nouă în lumina noilor săpături (1961-1963) [The importance of the Lumea Nouă Neolithic complex in the light of new research (1961-1963)]. Apulum, VII/I, 53-59.

Mapire (2016). Retrieved March 15, 2016, from http://mapire.eu/en/map/firstsurvey/

Mapire (2016). Retrieved March 15, 2016, from http://mapire.eu/en/map/secondsurvey/

Google Maps (2016). Retrieved March 15, 2016, from https://www.google.ro/maps/

Ciută, B. (2009). Cultivarea plantelor în pre și protoistoria bazinului intracarpatic din România [Plants growing in pre and protohistory of the Romanian intracarpathian basin]. Alba Iulia: Ed. Altip.

Cserni, B. (1888). Gyulafehérvar Florája [The flora of Alba Iulia], Gyulafehérvar.

Gligor, M. (2003). O figurină antropomorfă aparținând culturii Petrești de la Alba Iulia-Lumea Nouă [An antropomorphic figurine belonging to Petrești culture from Alba Iulia-Lumea Nouă]. Sargetia, 31, 51-57.

Gligor, M. (2007). Cercetări arheologice preventive la Alba Iulia-Lumea Nouă. O descoperire aparţinând grupului Foeni [Rescue excavations at Alba Iulia-Lumea Nouă. A discovery belonging to Foeni culture]. Apulum, XLIV, 1-28.

Gligor, M. (2009). Așezarea neolitică și eneolitică de la Alba Iulia-Lumea Nouă în lumina noilor cercetări [Alba Iulia-Lumea Nouă Neolithic and Eneolithic settlement in the light of recent research]. Cluj-Napoca: Ed. Mega.

Gligor, M. (2010). Funerary discoveries in neolithic settlement from Alba Iulia-Lumea Nouă (Romania). Multiple burial or ritual centre? Transylvanian Review, XIX, 5:1, 233-250.

Gligor, M. (2013). An Unknown Part of Prehistoric Spirituality: Unusual Mortuary Practices in Transylvania. European Journal of Science and Theology, 9(6), 201-210. 
Gligor, M. (2014). Începuturile eneoliticului timpuriu în Transilvania: o abordare Bayesiană [The beginning of Early Eneolithic in Transylvania: a Bayesian approach]. Analele Banatului, XXII, 91-105.

Gligor, M. \& McLeod K. (2014). Disarticulation as a mortuary practice in Early Eneolithic Transylvania? A case study from Alba Iulia - Lumea Nouă. Annales Universitatis Apulensis, Series Historica, 18/II, 61-86.

Gligor, M. \& McLeod, K. (2015). Disposal of the dead. Uncommon mortuary practices from Alba Iulia-Lumea Nouă 2003 excavation, in R. Kogălniceanu, M. Gligor, R. Curcă, S. Straton (Eds), „Homines, Funera, Astra 2”. Life beyound death in ancient times. Proceedings of the International Symposium on Funerary Anthropology. 23-26 September 2012, ' 1 Decembrie 1918' University (Alba Iulia, Romania), Oxford, Archaeopress, 25-41.

Gligor, M., Roșu, M., \& Panaitescu, V. (2012). Bioarchaeological Inferences from Neolithic Human Remains at Alba IuliaLumea Nouă (Romania), in R. Kogălniceanu, R. Curcă, M. Gligor, S. Straton (Eds.), „Homines, Funera, Astra”. Proceedings of the International Symposium on Funerary Anthropology. 5-8 june 2011, '1 Decembrie 1918' University (Alba Iulia, Romania), Oxford, Archaeopress, BAR International Series 2410, 57-70.

Iliescu, A. F. (2008). Arhitectura peisageră [Landscape gardening]. București: Ed. Ceres.

Iliescu, A. F. (2014). Istoria artei grădinilor [Garden history]. Bucureşti: Ed. Ceres.

Milea, A. P. (2011). Grădini istorice din Transilvania [Historical gardens from Transylvania]. Unpublished PhD Thesis. ClujNapoca.

Moga, V. (1987). De la Apulum la Alba Iulia fortificațiile orașului [From Apulum to Alba Iulia the fortress of the city]. București: Ed. Sport-Turism.

Stanciu, L. (2015). New World. Retrieved from http://edu.kindergraff.ro/BBB/single.php?lang=en\&storyid=19

Timonea, D. (2015). Unde se distrau locuitorii din Alba Iulia în urmă cu 100 de ani: lacurile și terasele din Lumea nouă [Where the citiziens of Alba Iulia had fun 100 year ago: the lakes and terraces from Lumea Nouă]. Retrieved from http://m.adevarul.ro/locale/alba-iulia/unde-distrau-locuitorii-alba-iulia-urma-100-ani-lacurile-terasele-lumea-noua1_55aa4af9f5eaafab2caf67ca/index.htm 